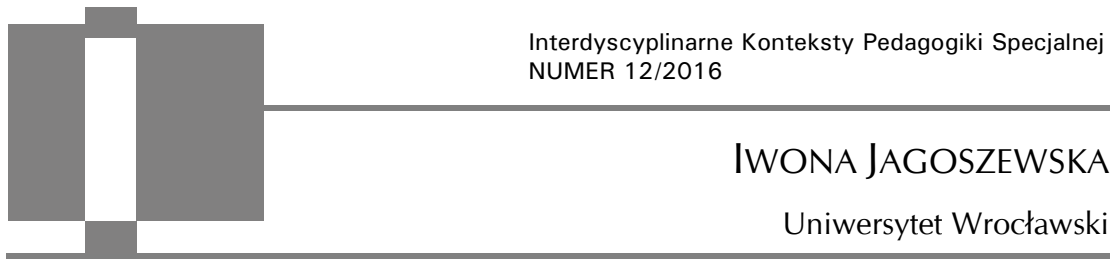

\title{
W poszukiwaniu drogi do emancypacji - oczekiwania niesłyszących
}

\begin{abstract}
Iwona Jagoszewska, $W$ poszukiwaniu drogi do emancypacji - oczekiwania niestyszacych [In search for ways of emancipation - expectations of deaf]. Interdyscyplinarne Konteksty Pedagogiki Specjalnej, nr 12, Poznań 2016. Pp. 135-163. Adam Mickiewicz University Press. ISSN 2300-391X

Many of the questions posed in the discussion on the modern state education policy are those connected with the search for ways of emancipation of deaf. Many issues of practical importance refers to the expectations of the deaf determined by diversity and specificity of their functioning, aspirations for autonomy or complex expectations regarding access to sign language. All this happens with simultaneous constraints to meet existing needs and changes achieved in legislation with a clear increase in the expression of the vital interests of one group in an incoherent community of the deaf.
\end{abstract}

Key words: deaf, emancipation, sign language, deaf community

\section{Wstęp. Emancypacja i jej znaczenie dla niesłyszących}

Teorie emancypacyjne już w drugiej połowie XX w. funkcjonowały wśród koncepcji pedagogicznych odnoszących się do wolności ludzi i wychowania. W koncepcjach tych podkreślano m.in. rolę procesu emancypacyjnego, w którym osoby lub grupy uzyskały wyzwolenie, podmiotowość i rzeczywisty wpływ na kontekst spo- 
łeczno-polityczny, w jakim funkcjonowały ${ }^{1}$. Wynikiem szybko następujących przemian społecznych, procesów globalizacji i migracji skomplikowanie kontekstów edukacyjnych stało się wyzwaniem dla współczesnych społeczeństw, w których wszyscy ludzie mają być traktowani podmiotowo i bez dyskryminacji.

W niniejszym artykule skupiono się na rozpoznaniu oczekiwań niesłyszących $w$ drodze do stopniowej zmiany miejsca w społeczeństwie, procesu emancypacji w systemie. Biorąc pod uwagę współczesne tendencje $\mathrm{w}$ zakresie pedagogiki oraz inspirowane osiągnięciami nowoczesnej teorii pedagogiki specjalnej postulaty upowszechnienia czy też pogodzenia teorii emancypacyjnych z praktyką, można m.in. konfrontować poprawę stopnia emancypacji tej grupy osób niepełnosprawnych do polityki społecznej państwa.

Niewątpliwie cennym źródłem wiedzy o emancypacji wychodzącym naprzeciw postulatom jej upowszechnienia $\mathrm{w}$ pedagogice są opracowania teoretyczne, dzięki którym emancypacja staje się faktem. Obecność i widoczność emancypacji jest swoistym przesłaniem cennych przemyśleń Marii Czerepaniak-Walczak. Wskazuje ona na związki wynikające $\mathrm{z}$ relacji pomiędzy emancypacją a wychowaniem, pisze m.in. o warunkach osiągania wolności i korzystania z niej jako kluczowym zadaniu współczesnych nauk o wychowaniu ${ }^{2}$. Wykorzystanie teorii emancypacji wpłynęło na rozumienie procesów edukacyjnych jako świadomej działalności skierowanej na usamodzielnianie i uwalnianie się podmiotu od ograniczeń3.

Także Bogusław Śliwerski uznaje posiadanie kompetencji emancypacyjnych odpowiedzialnych za umożliwienie i dostrzeganie ogra-

${ }^{1}$ H. Kostyło, Przestanie „Pedagogii uciśnionych" Paula Freire, „Forum Oświatowe” 2011, nr 2(45), s. 10, Documents\%20and\%20Settings/uw/Pulpit/194-594-1-SM.pdf [12.02.2016].

2 M. Czerepaniak-Walczak, Pedagogika emancypacyjna, rozwój świadomości krytycznej człowieka, Gdańskie Wydawnictwo Psychologiczne, Gdańsk 2006, s. 21.

${ }^{3}$ M. Czerepaniak-Walczak, Między dostosowaniem a zmianą. Elementy emancypacyjnej teorii edukacji, Wydawnictwo Naukowe Uniwersytetu Szczecińskiego, Szczecin 1995 , s. 40. 
niczeń, przełamywanie ich oraz wprowadzanie zmian ${ }^{4}$. Określa terminy „emancypacja” czy „wolność” jako kluczowe hasła reformatorskich inicjatyw w systemach oświaty ${ }^{5}$.

Sposób wykorzystania emancypacyjnych szans kształtowany jest przez ciągłe zmiany na gruncie pedagogiki specjalnej. Można zauważyć, że obecnie charakteryzuje ją znaczny wzrost znaczenia emancypacji jako motywacji i uzasadnienia działań. Amadeusz Krause rozpatruje dość szeroko paradygmaty pedagogii specjalnej, widząc w nich m.in. teoretyczny nurt krytyczno-emancypacyjny na rzecz poprawy sytuacji osób niepełnosprawnych i weryfikacji stosunku do tych osób6. Trafne wydaje się zwłaszcza jego stwierdzenie, że największym zadaniem najbliższych lat staje się połączenie nowoczesnej teorii pedagogiki specjalnej z realizacją zadań praktycznych.

Jak zatem teoria emancypacji może działać w polskich warunkach na praktyczne podwyższenie poczucia równości, wolności, korzystania z praw osób z wadą słuchu? Ponieważ zarówno w teorii, jak i w praktyce pedagogicznej uwzględniany jest model podmiotowego podejścia do człowieka, najwłaściwsze wydaje się, by nośnikiem emancypacji byli sami niesłyszący, mówiący o potrzebach wszystkich osób z wadami słuchu. Na drodze do realizacji swoich oczekiwań są gotowi na wiele poświęceń. Na zdobycie większych uprawnień oprócz świadomości emancypacyjnej zarówno poszczególnych osób z wadą słuchu, jak i ich organizacji składają się też warunki takie jak sfera polityki państwa, regulacje prawne, edukacja, prawo pracy czy opieka socjalna. Oczekiwania niesłyszących wiążą się z postrzeganiem możliwości poprawy dla swojego funkcjonowania i domagania się decydentów by zagwarantowali im swobodę i równość w dostępie do dóbr społecznych. Niewątpliwie

${ }^{4}$ B. Śliwerski, Edukacja alternatywna. Dylematy teorii i praktyki, Oficyna Wydawnicza „Impuls”, Kraków 1992, s. 52.

${ }^{5}$ B. Śliwerski, Wspótczesne teorie i nurty wychowania, Oficyna Wydawnicza „Impuls", Kraków 2003, s. 264-265.

${ }^{6}$ A. Krause, Teoretyczne inspiracje pedagogiki specjalnej - pedagogika emancypacyjna, „Studia Edukacyjne” 2013, nr 28, s. 7-16. 
ta grupa niepełnosprawnych boryka się z trudnościami zwłaszcza komunikacyjnymi oraz na rynku pracy. Jednakże problemy z zatrudnieniem nie są obce większości ludzi w Polsce - wydaje się, że nigdy nie będzie dosyć środków finansowych, by uwolnić od nich wszystkich obywateli.

Dorota Podgórska-Jachnik nakreśla szeroki kontekst zjawiska emancypacji osób głuchych, przedstawia osiągnięcia i trudności emancypacji tej grupy związane m.in z dążeniami do uzyskania wykształcenia oraz „do uznania kultury i języka Głuchych jako przejawu zbiorowej emancypacji"7. Wyrazem namysłu autorki nad rzeczywistością osób niesłyszących są obszerne prezentacje analiz kontekstu indywidualnych emancypacji pierwszego pokolenia studentów z uszkodzonym słuchem, którzy masowo zaczęli pobierać naukę na wyższych uczelniach. Najważniejszym symptomem emancypacji są tzw. pasaże edukacyjne, rozumiane jako „specyficzne przejścia od dzieciństwa pod znakiem niepełnosprawności do wyzwolonej od niej dorosłości" stanowią zdaniem tej specjalistki źródło kapitału emancypacyjnego ${ }^{8}$. Z tej perspektywy działania edukacyjne niesłyszących nabierają konkretnych wymiarów i znaczenia umożliwiającego emancypację.

Kontynuowanie nurtu emancypacyjnego powinno doprowadzić do dynamicznego wzrostu elastycznych działań ukierunkowanych na usamodzielnienie, podniesienia poczucia ważności edukacji, tożsamości i wolności zarówno wśród samych niesłyszących, jak i świadomości osób z nimi związanych, takich jak nauczyciele, terapeuci, decydenci Tym samym poszukiwanie możliwych dróg emancypacji wyznacza kierunki, wykorzystuje okoliczności, które pomogą zainteresowanym na uruchamianie samodzielności poprzez działanie. Ważnym aspektem tej populacji jest utrzymanie stałej gotowości do praktycznych działań emancypacyjnych w celu utrzymania ich na wysokim poziomie. Warto przyjrzeć się sytua-

7 D. Podgórska-Jachnik, Gtusi. Emancypacje, Wydawnictwo Naukowe WSP, Łódź 2013, s. 9.

8 Ibidem, s. 12. 
cjom dotyczącym wybranych oczekiwań niesłyszących walczących o zwiększenie stopnia swojej emancypacji.

Polscy niesłyszący osiągnęli wiele sukcesów ale odnieśli też sporo porażek w różnych wymiarach społecznego zróżnicowania. W tym miejscu wypada stwierdzić, iż znaczna aktywność niesłyszących obserwowana na przestrzeni ostatnich lat, $z$ jednej strony jest źródłem postępu, jednak z drugiej strony nie towarzyszyła jej równie wysoka poprawa emancypacji głuchych w praktycznym życiu społecznym. Do dziś obszar najtrudniejszy i najsłabiej przystający do współczesnych wymagań i oczekiwań niesłyszących stanowi praktyka.

\section{Dostosowanie terminologii do specyfiki osób niesłyszących}

Niesłyszący, podobnie jak inne grupy, funkcjonują w zróżnicowanej przestrzeni społecznej, w której pewne cechy indywidualne, takie jak m.in. niepełnosprawność, wyznaczają określone miejsce. Odczytując pojęcia przypisane do osób z wadą słuchu, można rozpatrywać je w kontekście oceny stopnia niepełnosprawności (osoby odznaczające się najwyższym stopniem niepełnosprawności potrzebują największego wsparcia - dość często uzyskują jednak najniższe wykształcenie). Można się zastanawiać, na ile istotne jest postrzeganie terminologii, która odnosi się do całej populacji niesłyszących oraz do społeczeństwa, w jakim funkcjonują. Swoim zakresem pojęcie głuchoty obejmuje cele i wartości wspólne dla wszystkich osób z ubytkiem słuchu, tj. osoba, funkcjonowanie, porozumiewanie się, społeczeństwo. Zakres pojęciowy głuchoty nieustannie się zmienia, stąd też konieczne jest zrozumienie ich znaczenia i sensu, co pozwali osobom niesłyszącym, mimo ubytku słuchu, na zdobywanie coraz większych uprawnień także w tzw. idealnym społeczeństwie równych szans dla wszystkich jego członków.

W rozważaniach na temat osób niesłyszących specjaliści zajmujący się zagadnieniami związanymi z osobami z uszkodzonym 
zmysłem słuchu zgodnie podkreślają występowanie znaczących różnic $\mathrm{w}$ tej populacji, co $\mathrm{w}$ istoty sposób wpływa na stosowanie przyjętej terminologii ${ }^{9}$. Taka różnorodność wynika m.in. z odmiennych kryteriów kwalifikacyjnych, które są przyjmowane do ich tworzenia oraz uwarunkowań celom, jakim ma służyć. Brak jednolicie przyjętego i precyzyjnego rozróżnienia pojęć powoduje m.in. trudności w rozumieniu kogo uważamy za osobę z uszkodzonym narządem słuchu. Aby podjąć próbę zinterpretowania specyfiki emancypacji niesłyszących, należy dokonać chociażby częściowej egzemplifikacji przyjętych pojęć. Wskazać można m.in. na trudności związane z odmiennością terminologii różnych dziedzin nauki, którą należy uwzględnić, łącząc obszary o różnym stopniu oddziaływań, które przyczyniają się do wyodrębnienia pojęcia. Współczesne nazewnictwo wykorzystuje:

- w przepisach prawa Ministerstwo Edukacji Narodowej określa, iż „uczeń niepełnosprawny: uczniowie (...) mający trudności w uczeniu się i/lub komunikowaniu się, w tym uczniowie niesłyszący i słabosłyszący" 10 ;

- w orzecznictwie stosuje się ustalenia terminologiczne zalecone przez Międzynarodowe Biuro Audiofonologii11. Bogdan Szczepankowski przeprowadza szeroką analizę stosowanych definicji osób głuchych, niesłyszących, niedosłyszących i sła-

${ }^{9}$ Y. Csanyi, Stuchowo-werbalne wychowanie dzieci z uszkodzonym narządem stuchu, WSiP, Warszawa 2004; A. Korzon, Znaczenie języka migowego we wczesnej komunikacji dzieci z zaburzeniami stuchu, [w:] Dziecko niepetnosprawne. Rozwój i wychowanie, red. E. Minczakiewicz, Oficyna Wydawnicza „Impuls”, Kraków 2003; D. Podgórska-Jachnik, Głusi. Emancypacje...; B. Szczepankowski, Niestyszący - Gtusi - Gtuchoniemi. Wyrównywanie szans, WSiP, Warszawa 1999; P. Tomaszewski, Rozwijanie kompetencji socjokulturowej w nauczaniu polskiego jezyka migowego, [w:] Społeczne i kulturowe aspekty zdrowia $i$ niepetnosprawności, red. P. Tomaszewski, K. Bargiel-Matusiewicz, E. Pisula Wydawnictwo UW, Warszawa 2015.

10 https://men.gov.pl/niezbednik [20.02.2016].

11 B. Hoffman, Surdopedagogika w teorii i praktyce, WSP TWP, Warszawa 2001, s. 16; B. Szczepankowski, Niestyszacy - Głusi - Głuchoniemi. Wyrównywanie szans, WSiP, Warszawa 1999, s. 42. 
bosłyszących ${ }^{12}$. Proponuje on przyjęcie definicji, w której: osoba $\mathrm{z}$ uszkodzonym słuchem w stopniu lekkim, umiarkowanym, znacznym lub głębokim jest to osoba, której uszkodzenie słuchu, określone audiogramem progowym i przeliczone według tabeli Międzynarodowego Biura Audiofonologii (BIAP), przekracza 20 dB i kwalifikuje ją do jednego ze stopni uszkodzeń;

- w pracach specjalistycznych w dziedzinie medycyny występują terminy: „upośledzenie słuchu” i „zaburzenie słuchu”13;

- w surdopedagogice różnice dotyczą samego terminu, istoty rozumieniu pojęcia głuchoty jak również traktowania jej w odmienny sposób ${ }^{14}$. Dostrzega się m.in. związki z funkcjonowaniem społeczno-emocjonalnym, samooceną, jakością życia i tożsamością jako osoby głuchej, dzieci i młodzieży głuchej (słabosłyszącej), uczęszczających do różnych placówek edukacyjnych ${ }^{15}$;

- uwzględniając funkcjonowanie językowe, w sferze percepcji i recepcji mowy zaleca się wyróżnienie osób z uszkodzeniami słuchu jako: "funkcjonalnie słyszące”, , "niedosłyszące”, , słabosłyszące” oraz "funkcjonalnie niesłyszące (głuche)”16. Choć można wyróżnić wśród wszystkich osób z uszkodzeniami słuchu co najmniej 107 grup. Każda z nich wymaga indywidualnego podejścia w rehabilitacji i edukacji17;

12 Ibidem, s. 41 i n.

${ }^{13}$ H. Skarżyński, M. Mueller-Malesińska, W. Wojnarowska, Klasyfikacja zaburzeń stuchu. „Logopedia” 2002, nr 28, s. 12.

${ }^{14} \mathrm{~K}$. Plutecka, Kompetencje zawodowe surdopedagoga z wada stuchu, Oficyna Wydawnicza „Impuls”, Kraków 2006, s. 22.

15 J. Kobosko, Edukacja głuchych. Materiaty konferencyjne, RPO, Warszawa 2014, s. 51.

${ }^{16}$ K. Krakowiak, Szkice o wychowaniu dzieci z uszkodzeniami stuchu, Oficyna Wydawnicza Fundacji Uniwersyteckiej w Stalowej Woli, Stalowa Wola 2003, s. 36.

${ }^{17}$ K. Krakowiak, Pedagogiczna typologia uszkodzeń stuchu i osób nimi dotkniętych, [w:] "Nie głos, ale stowo..." Przekraczanie barier w wychowaniu osób z uszkodzeniami stuchu, red. K. Krakowiak, A. Dziurda-Multan, Wydawnictwo KUL, Lublin 2006, s. 282-287. 
- w logopedii za podstawowe określenie w rozumieniu osoby z uszkodzonym słuchem uznaje się preferowany sposób porozumiewania się oraz ogólny poziom rozwoju psychofizycznego ${ }^{18}$;

- równie istotny jest relatywizm pojęcia głuchoty oraz jego związek z warunkami socjoekonomicznymi danego kraju. Tam, gdzie istnieje wczesne diagnozowanie, dobre przystosowanie aparatów słuchowych, odpowiednie wychowanie i kształcenie, termin ten może nie obejmować osób, które w innych krajach są uznawane za głuche;

- pomiędzy dwoma światami_trudno określić, kto jest głuchym, osoby z uszkodzonym słuchem, którzy nie są w stanie spełnić wymogów ani społeczności głuchych ani słyszących ${ }^{19}$;

- wiedza o sytuacji społecznej osób głuchych poprzez dostrzeżenie świadomości odmienności społeczności głuchych i dążenia do jej wyartykułowania wyjątkowość osób głuchych20;

- w środowisku głuchych występują podziały i klasyfikacje np. na „mniej głuchych” i „bardziej głuchych”. Dostrzegany jest również nowy typ człowieka niesłyszącego tzw. „idealnego głuchego"21. Zatem osoby $\mathrm{z}$ wadą słuchu to zróżnicowana grupa społeczna dość często dzielona na: głuchych, niesłyszących, słabosłyszących;

- w dialogu z uwagi na zachodzące zmiany, np. zastosowanie aparatów słuchowych spowodowało, że wiele osób z nich korzystających, którzy jeszcze w niedawnej przeszłości byliby

18 G. Gunia, Terapia logopedyczna dzieci z zaburzeniami stuchu i mowy. Wybrane problemy teorii i praktyki surdologopedy, Oficyna Wydawnicza „Impuls”, Kraków 2006, s. 26.

${ }^{19}$ U. Bartnikowska, Sytuacja społeczna i rodzinna styszacych dzieci niestyszących rodziców, Wydawnictwo edukacyjne AKAPIT, Torun 2010, s. 85.

20 D. Podgórska-Jachnik, Głusi. Emancypacje..., s. 102.

${ }^{21}$ D. Podgórska-Jachnik, Głusi. Emancypacje...; D. Podgórska-Jachnik, Głusi wśród styszących - głusi wśród Głuchych. Problemy integracji społecznej osób z uszkodzonym stuchem w aspekcie tożsamościowym, [w:] Tożsamość społeczno-kulturowa głuchych, red. E. Woźnicka, Polski Związek Głuchych Oddział Łódzki, Łódź 2011. 
nazwani niesłyszącymi, obecnie można nazwać w znacznym stopniu słyszącymi, oraz w odniesieniu do osób z uszkodzeniem słuchu w stopniu lekkim, które na tyle dobrze i samodzielnie funkcjonują w społeczeństwie, że nie ma konieczności tworzenia dla nich odrębnego pojęcia22. Można nazywać je „osobami lekko niedosłyszącymi” 23 .

Wspólna rzeczywistość niesłyszących charakteryzuje się zróżnicowaniem, zmiennością, wieloznacznością w wielu zakresach i na różnych płaszczyznach funkcjonowania. W tekście wykorzystano terminologię na tle aktualnie obowiązujących w Polsce przepisów prawa (MEN: niesłyszący, słabosłyszący) przy czym używa się także pojęcia Głusi/głusi oraz osoby z uszkodzonym słuchem, ponieważ podkreślają one specyfikę osób, którzy są przedmiotem rozważań.

\section{Zorientowanie na zmianę}

Zmiany zachodzą w ogólnym profilu człowieka z wadą słuchu oraz wielu dziedzin życia. Rosnąca liczba osób, które doświadczają uszkodzeń słuchu, wymusza zastanowienie się nad ich specyfiką. Aktualnie ich liczba wynosi kilka milionów, ponad 100 osób rocznie traci słuch w wyniku różnych wypadków ${ }^{24}$. Szacuje się, iż co trzeci Polak niedosłyszy przynajmniej na jedno ucho na poziomie $30 \mathrm{~dB}$. Warto dodać, iż niemal 20\% Polaków odczuwa szumy uszne będące początkowym stadium niedosłuchu ${ }^{25}$.

22 K. Krakowiak, Szkice o wychowaniu dzieci z uszkodzeniami stuchu, Oficyna Wydawnicza Fundacji Uniwersyteckiej w Stalowej Woli, Stalowa Wola 2003, s. 36.

${ }^{23}$ B. Szczepankowski, Jezzyk migowy a mowa ciała, [w:] Mowa ciała i jej funkcje w kulturze, red. M. Jasińska, J. Kuć, Wydawnictwo Akademii Podlaskiej, Siedlce 2002, s. 127-138.

24 http://resgest.pl/wp-content/uploads/2016/01/zatrudnij_gluchych_broszu ra.pdf [15.03.2016].

${ }^{25}$ K. Werszka, K. Bieńkowska-Robak, Problemy ze stuchem, „Integracja” 2002, nr 6, s. 79 . 
Znaczący postęp dokonujący się w medycynie powoduje wzrost gwarancji bezpieczeństwa dla podjęcia operacji „przywracających słuch". Stosunkowo niedawno ci, którzy decydowali się na wszczepienie implantu ślimakowego, byli uznawani za ryzykantów wprowadzających do swojego ciała obcy przedmiot, a ponadto skutkiem tej decyzji było zrywanie więzi ze środowiskiem głuchych. Jednak jak dowodzą badania, coraz większa liczba osób jest gotowa do implantowania, a znaczącą ich część stanowią dzieci słyszących rodziców niemające przeszłości jako głusi. Ciekawe skutki umiejętnie prowadzonej medycznej strategii operacyjnej poprawy słuchu dotyczą wzrostu liczby dokonywania operacji przez dorosłych głuchych. Czy po udanym wszczepie są nadal głusi, czy można ich uznać za słyszących? Trudno jest przyjąć ogólne stanowisko, gdyż mogą występować rożne motywy interpretacji. Słyszący w swojej percepcji postrzegania rzeczywistości nie do końca są w stanie uznać za słyszących osoby zaimplantowane, u których nadal zauważyć można trudności w płynnym wypowiadaniu się, ograniczenia w odbiorze dźwięków oraz można przewidywać potrzebę długotrwałej rehabilitacji mowy. Głusi wraz z ideologią, z którą się identyfikują, są dumni z bycia głuchym i pielęgnują przekonanie o swojej wyjątkowości, skutkiem czego zdarzają się czarno-białe wyobrażenia, bez dostrzegania stanów pośrednich choć rodziny i przyjaciele dopuszczają implantacje ze względów medycznych (szumy uszne). Na podstawie badań leczenia głuchoty za pomocą stymulacji implantami oraz prób poszukiwania nowych metod terapeutycznych można dzisiaj stwierdzić, że są one skuteczniejsze niż postępowanie konwencjonalne26.

Dostrzeżenie obiektywnym okiem zmian wymaga pewnego oddalenia pozwalającego na przyjęcie szerokiej perspektywy. Wydaje się, iż konieczne jest odpowiedzialne współuczestnictwo wszystkich osób z wadą słuchu, co wiąże się ze zdolnością do współpracy

26 D. Raj-Koziak, Sprawozdanie z 9th Internayional TRI Tinnitus Conference 'Tinnitus: from Cochlea to Brain and Back” 7-10.06.2015 Ann Arbor USA, „Nowa Audiofonologia" 2015, nr 4(3) s. 84-85. 
w oparciu o wzajemny szacunek i zrozumienie. W specyfice środowiska osób z wadą słuchu nie ma zdecydowanego jednego ośrodka władzy czy przywódcy, istnieje znaczna liczba stowarzyszeń, organizacji terenowych i społecznych, osób indywidualnych z których tylko część wpływa na siebie nawzajem (jak w Polskim Zarządzie Głuchych). Dość często skupiają się na postrzeganiu własnych trudności i sukcesów, co nie zawsze służy tworzeniu sprzyjających warunków do odpowiedzialnego korzystania, choćby tylko z równych praw. Okazuje się, że istnieje cały szereg rozmaitych elementów, które w mniejszym lub większym stopniu dezorganizują np. proces inkluzji. Zwracają uwagę zwłaszcza aspekty wzajemnego wpływania na siebie środowisk głuchych i słabosłyszących. Podkreśla się, iż środowiska te są zupełnie inne, mają odmienne problemy i potrzeby, a sami głusi mogą i mają prawo wypowiadać się za siebie. Dzięki sprzyjającym okolicznościom może ujawnić się zarówno dobry, jak i negatywny wpływ tych środowisk. Działania w środowisku głuchych są uwarunkowane jeszcze jedną okolicznością, która obrazuje zróżnicowanie oceny wsparcia poprzez odróżnienie wykorzystywania głuchych i słabosłyszących od pomocy z dobrej woli. Niezbędna jest dalekowzroczność w stosowaniu bodźców mobilizujących do działań.

Warto zatrzymać się także przy zagadnieniu tzw. toksycznych głuchych i słabosłyszących oraz ich wpływie na środowisko osób z wadą słuchu. Krytykowanie osób późnoogłuchłych, którzy wypowiadają się w imieniu osób głuchych, wskazuje na nadmierną wrażliwość i brak porozumienia środowiska.

Dość znaczące wydają się współczesne relacje między pokoleniem młodszych i starszych niesłyszących. Chodzi przede wszystkim o spojrzenie na interesujący układ sił pomiędzy nimi wraz z występującymi zależnościami. Prawdopodobieństwo tworzenia sprzyjającego inkluzji klimatu może znacząco zmniejszać się z powodu pogłębiających się różnic językowych, słabego zaangażowania w używanie czystego Polskiego Języka Migowego. Młodzi niesłyszący skutecznie wykorzystują internet jako nowy środek komunikacji. Porozumiewają się z osobami, które mają podobne 
problemy np. portal dla Niesłyszących i Słabosłyszących Internautów ONSI27, co oznacza jednak integrację ograniczoną do konkretnych uczestników. Tworzą nowy rodzaj środowiska, które ma ogromny wpływ na aktywne działania młodzieży niesłyszącej28. Kwestia ta nabiera dużego znaczenia w praktyce, gdzie stykają się osoby głuche praktycznie wykluczone cyfrowo z liczną grupą młodych niesłyszących internautów. Zasadniczy zwrot $w$ funkcjonowaniu głuchych nastąpił wraz z rozwojem internetu, w którym poprzez komunikację online powstają nowe wzorce stosunków społecznych. Ta forma komunikacji wzbogaca dążenia osób z wadą słuchu do autonomii i jest wartościowy w odniesieniu do działań emancypacyjnych i wolnościowych, bowiem pozwala na swobodą organizację bez udziału państwa.

\section{Dążenie do autonomii}

Przeszłość i teraźniejszość osób niesłyszących przeplata się z oczekiwaniami wobec przyszłości. Samo wprowadzenie zmian nie powoduje rozwiązania wszystkich trudności, ale prowadzi do poszukiwania najefektywniejszych dróg rozwoju, gotowości zainteresowanych do angażowania się do pracy oraz korzystania z przepisów prawa. Trzeba podkreślić aktywność omawianej grupy niepełnosprawnych dążącą do poprawy ich sytuacji. To, co warto zauważyć, to znaczna świadomość niesłyszących związana ze swoistym powiązaniem ludzi zrzeszonych $\mathrm{w}$ organizacjach pracujących na ich rzecz. Znają istniejące organizacje oraz te nowopowstające, wspierają stowarzyszenia, zwykle interesują się nimi i chcą je poznać. Obszar związany $\mathrm{z}$ organizacjami, stowarzyszeniami czy aktywistami działającymi $w$ kręgu niesłyszących wciąż się zmienia i rozbudowuje. Niesłyszący otrzymują w nich nie tylko elementarne mechanizmy wsparcia, mogące być początkiem nowych działań, ale też możliwości stworzenia sobie kontaktów towarzyskich.

\footnotetext{
27 https:/ / www.onsi.pl [17.02.2016].

28 http:/ / www.youtube [17.02.2016].
} 
Wynika to m.in. z charakterystycznym dla tej grupy zaufaniem do osób spoza własnej rodziny, która często jest słysząca. Jak podkreśla Joanna Kobosko, w zdecydowanej większości, tj. w około 95\%, dzieci głuche przychodzą na świat w rodzinach słyszących, które nie miały $\mathrm{w}$ dotychczasowym życiu kontaktu $\mathrm{z}$ osobami głuchymi ${ }^{29}$. Osoby ze znacznym i głębokim uszkodzeniem słuchu $\mathrm{w}$ pozaintegracyjnej drodze rozwoju $\mathrm{w}$ wielu przypadkach kształcą się, a potem $\mathrm{w}$ przyszłej pracy zawodowej $\mathrm{w}$ sposób naturalny funkcjonują $\mathrm{w}$ środowisku niesłyszących $\mathrm{np}$. w szkole $\mathrm{z}$ internatem czy zakładzie pracy. Nie musi to oznaczać zwiększenia dystansu między osobami $z$ wadą słuchu, jednak może prowadzić do wspomnianego już podziału środowiska osób z wadą słuchu (klasyczny przykład takiego podziału wyodrębnia grupy: głusi, niesłyszący, słabosłyszący).

Z pewnością warto zwrócić uwagę na czynnik niezwykle frustrujący i negatywnie wpływający na samodzielność osób z wadą słuchu. Według projektu PFRON-u koordynowanego przez Annę Izabelę Brzezińską: „Ogólnopolskie badanie sytuacji, potrzeb i możliwości osób niepełnosprawnych" na lata 2008-2010 wynika, że 73,7\% populacji osób z uszkodzonym słuchem (w wieku 16-59 lat) nie pracowało ${ }^{30}$. W rozważaniach podjętych $\mathrm{w}$ tym opracowaniu dość istotne wydaje się położenie nacisku na wyeksponowanie zalet w dążeniach do samodzielności, celem podjęcia próby odpowiedzi na pytanie, jakie drogi emancypacji powinny przybierać działania osób z wadą słuchu. Pewnym optymizmem napawa fakt, iż obok wymienionych wersji podziału, istnieją zarazem silne dążenia integracyjne. Głusi z różnych krajów łączą się w grupy społeczne, nasilają się ruchy konsolidacyjne, w ramach których domagają się określenia siebie jako językowa i kulturowa mniejszość.

${ }^{29}$ J. Kobosko, Edukacja głuchych. Materiaty konferencyjne, RPO, Warszawa 2014, s. 41 .

${ }^{30}$ www.efs.20072013.gov.pl/analizyraportypodsumowania/baza_projektow_ badawczych_efs/strony/ogolnopolskie_badanie_syt_potrzeb_2009_28032011.aspx [6.01.2016] 
Warto podkreślić, że głusi, dostrzegając ograniczenia w polskich możliwościach społeczno-ekonomicznych, pokazują, iż ważne dla nich jest uzyskanie przywilejów (manifestacje głuchych w latach 2013 i 2014)31. O tym, jak trudne jest to w praktyce, świadczą problemy w nawiązaniu realnej współpracy w ramach zróżnicowanego i niejednorodnego środowiska osób niesłyszących, a także wzmocnienie więzi ze słyszącymi z zachowaniem prawa do różnorodności i odrębności. Z tego powodu ważne znaczenie mogą mieć dokonujące się dziś procesy demokratyzacji państwa, w które wplecione są manifestacje osób głuchych na ulicach Warszawy - pierwsza, z 1 lipca 2013 r. w obronie praw, wolności i kultury głuchych w Polsce, druga 28 lutego 2014 r. Pozostają one w ścisłym związku $\mathrm{z}$ toczącymi się sporami o konsekwencje kryzysu w relacjach między pokoleniem młodszych i starszych niesłyszących ze względu na pogłębiające się różnice językowe, zanikanie czystego Polskiego Języka Migowego czy wpływu postępu technologicznego na język migowy i kulturę głuchych. Wszystkie te elementy są ze sobą związane ze względu na dokonujące się w stosunkach społecznych dążenia do równości i wolności.

Aktualnie w Polsce na skutek wieloletnich działań i przy sprzyjającym zmianom politycznym klimacie jest szansa na osiągnięcie postępu w kierunku włączania społecznego osób niesłyszących. Wydaje się jednak, że najwięcej mogą uzyskać ci, którzy są najgłośniejsi i najbardziej widoczni (obecnie są to zwolennicy Polskiego Języka Migowego - PJM, głusi). Z jednej strony żądania odpowiadają ich potrzebom i są zgodne z zasadami równości społecznej, z drugiej natomiast odnoszą się one bezpośrednio zaledwie do części reprezentacji całego środowiska osób z wadą słuchu. Podstawowa trudność związana jest z tym, że nie odpowiadają one wszystkim zainteresowanym, którzy są mniej widoczni albo nawet „zapomniani”. Domagając się równości, głusi nie dostrzegają, iż ograniczają przywileje innych, w tym także osób z wadą słuchu.

Tworzenie własnej tożsamości na bazie wolności wyraża się przez poszukiwanie grupowego sukcesu dzisiejszych głuchych.

${ }^{31}$ http://www.niepelnosprawni.pl/ledge/x/179419 [6.01.2016]. 
Wpływają oni na decydentów tak mocno dlatego, że działają na wielu płaszczyznach, a to czyni ich skuteczniejszymi. Wykorzystują, a czasami nawet nadużywają, określenia "my” jako przedstawiciele i reprezentanci całego środowiska osób $\mathrm{z}$ wadą słuchu, dając wrażenie wspólnoty i przynależności. Należałoby więc podjąć drażliwy społecznie temat wyrażania żywotnych interesów jednej grupy w niespójnym środowisku niesłyszących przy niemożności przemawiania jednym głosem. Potrzeba większej tolerancji i szerszej perspektywy, w związku z tym niezbędna jest stabilizacja przy uwzględnieniu demokratycznych zasad równości praw, w tym także praw innych osób niepełnosprawnych, nie tylko głuchych

W tym kontekście warto przedstawić celnie oddające stwierdzenia A. Krause, wedle którego we współczesnym społeczeństwie inkluzja dotyczy nie tyle problemu niepełnosprawności w tej czy innej formie, lecz podstawowej zasady równości szans. Głównym hasłem inkluzji społecznej jest przyjęcie za rzecz oczywistą, że wszyscy powinni mieć równe szanse. Przeobrażenia w ujęciu istoty integracji wpisują się $\mathrm{w}$ przemiany modelu samej niepełnosprawności i relacji społecznych osób niepełnosprawnych ${ }^{32}$. Usuwanie barier łączy się z osiągnięciem równości uczestnictwa w życiu społecznym.

W polskim systemie edukacji młodzież niepełnosprawna, w tym niesłysząca i słabosłysząca, ma możliwość kształcenia się we wszystkich typach szkół zgodnie $\mathrm{z}$ indywidualnymi potrzebami rozwojowymi i edukacyjnymi oraz predyspozycjami. MEN 17 listopada 2010 r. wprowadza sześć rozporządzeń regulujących zasady organizowania kształcenia specjalnego oraz udzielania pomocy psychologiczno-pedagogicznej dla dzieci i młodzieży niepełnosprawnej oraz niedostosowanej społecznie $\mathrm{w}$ przedszkolach, szkołach oddziałach ogólnodostępnych lub integracyjnych ${ }^{33}$.

32 A. Krause, Niepetnosprawność-Inny w paradygmacie humanistycznym, „Niepełnosprawność Półrocznik Naukowy. Surdopedagogika - Problemy Wybrane/Niepełnosprawność w aspekcie zdrowia i życia społecznego" 2010, nr 4, s. 111-121.

33 http:/ / www.bip.men.gov.pl/index.php [dostęp: 15.03.2016]. 
Aktualizacje $\mathrm{w}$ przepisach i zmiany $\mathrm{w}$ uregulowaniach prawnych tworzą nowe możliwości kształcenia uczniów niepełnosprawnych (w tym niesłyszących) w klasach integracyjnych i masowych. Obecnie w Polsce funkcjonuje 36 placówek oświatowych zajmujących się kształceniem osób głuchych i słabosłyszących m.in. przygotowujących do nauki na wyższych szczeblach. W większości są to specjalne ośrodki szkolno-wychowawcze, w ramach których działają szkoły podstawowe, gimnazja, szkoły ponadgimnazjalne i szkoły policealne. W roku szkolnym 2009/2010 w tego typu szkołach uczyło się 5986 dzieci i młodzieży głuchych i słabosłyszących, podczas gdy w szkołach specjalnych były to 2622 osoby. Jednocześnie likwidowane są niektóre placówki oświatowe dla głuchych, głównie z przyczyn finansowych ${ }^{34}$. Oprócz zadeklarowanych praw, osobom niepełnosprawnym należy zapewnić warunki do tego, aby z owych praw mogły korzystać. Jeśli mówimy o prawie do edukacji i pełnym dostępnie do nauki, istnieje potrzeba zastanowienia się, czy wszystkie placówki i instytucje związane $\mathrm{z}$ edukacją są przygotowane do kształcenia niesłyszących.

Cechą łączącą praktyków z osobami z wadą słuchu jest poszukiwanie wspólnej zasady respektowania potrzeb systemu oświaty z presją grupowych i indywidualnych preferencji niesłyszących. Jednym ze sposobów jest zmiana nazewnictwa szkół dla głuchych. Piotr Kowalski tłumacząc tę kwestię, podnosi, iż nauka w szkole specjalnej jest często, mimo poświęcenia i zaangażowania pracujących tam nauczycieli, stygmatyzująca. Istnieje społeczne przekonanie, że szkoła specjalna jest dla osób gorszych, niestety często głupszych. Częściowo można z tym stygmatem walczyć poprzez zmianę nazwy szkół. Zamiast używać określenia „specjalny ośrodek szkolno-wychowawczy” należałoby używać określenia „specjalistyczny ośrodek szkolno-wychowawczy"35.

34 E. Twardowska, M. Kowalska, Katalog szkół 2011/2012, Wydawnictwo PZG, Łódź 2011.

35 P. Kowalski, Rekomendacje organizacyjne dla szkolnictwa dla Gtuchych, [w:] Edukacja głuchych. Rzecznik Praw obywatelskich, RPO, Warszawa 2014, s. 129. 
Na skutek wprowadzania zmian $\mathrm{w}$ systemie edukacji systematycznie zmniejsza się liczba dzieci w normie intelektualnej w szkołach dla głuchych i niedosłyszących, a do szkół specjalnych dla głuchych przyjmowane są dzieci ze sprzężeniami. Ponadto widoczna jest wyraźna tendencja podejmowania nauki na wyższych etapach kształcenia w szkołach specjalnych przez zdolne dzieci i młodzież po ich porażce w szkołach masowych ${ }^{36}$. Od dość dawna specjaliści podkreślają, iż przyczyną może być zbyt niski poziom nauczania w szkole specjalnej.

Szczególne znaczenie dla powodzenia integracji, a $w$ dalszym etapie inkluzji osób niesłyszących, ma dążenie do uzyskania praw dla kształcenia w języku migowym. Dyskurs w tym zakresie toczy się od wielu lat. Poszukiwane są sposoby na tworzenie optymalnych warunków dla komunikacji. Przykładowo już w 1997 r. Ministerstwo Edukacji Narodowej wydało dokument „Kierunki przemian w kształceniu uczniów niepełnosprawnych", który zawierał punkt mówiący o prawie niesłyszącego dziecka do nauki w języku migowym.

Aktualnie, biorąc pod uwagę tendencje $\mathrm{w}$ zakresie przyszłego osiągnięcia pełni praw do edukacji bez dyskryminacji i na zasadach równych szans, można dostrzec, iż oczekiwania niesłyszących są rozbieżne z programem szkolnym. Teoretyczne zaplecze tych rozważań stanowią koncepcje sformułowane m.in. przez Mariusza Saka ${ }^{37}$. Jego zdaniem kształcenie integracyjne powinno obejmować:

- włączanie w program nauczania elementów tożsamości i kultury głuchych,

- zapewnienie wysokiego poziom przygotowania merytorycznego kadry,

- promowanie kontaktów z lokalną społecznością głuchych.

${ }^{36}$ C. Kosakowski, Dziecko niepetnosprawne w szkole masowej-możliwości i ograniczenia, [w:] Dziecko o specjalnych potrzebach edukacyjnych, red. C. Kosakowski, M. Zaorska, Wydawnictwo Edukacyjne, Toruń 2000, s. 59.

${ }^{37}$ M. Sak, Kształcenie głuchych w szkołach masowych i w klasach mieszanych z innymi niepetnosprawnościami, wystąpienie na Konferencji Edukacja Głuchych 20.03.2014. 
Natomiast $\mathrm{w}$ praktyce dominują działania o charakterze doraźnym, będące próbą odpowiedzi na postulaty, które wyraża część całej populacji osób z wadą słuchu. Wyzwaniem dla państwa pozostaje spełnienie tych oczekiwań. Jest to dość trudne w związku z tym, że ubiegając się o przywileje i opiekę ze strony państwa, jednocześnie funkcjonują $\mathrm{w}$ dość hermetycznym środowisku, które posługuje się własnym językiem, nie zabiegają o względy słyszących i nie utożsamiają się z nimi. Ponadto, jak podkreśla Piotr Tomaszewski, dystansują się od pojęcia niepełnosprawności, a głuchotę traktują nie jako złe doświadczenie bądź ułomność, lecz jako unikatową przypadłość, która stanowi dla nich klucz do własnej tożsamości ${ }^{38}$.

Nadmiernym uproszczeniem byłoby stwierdzenie, iż tylko $\mathrm{w}$ Polsce indywidualne sposoby zaspokajania potrzeby edukacji na poziomie wyższym nie są spełnione, choć wyniki dotychczasowych badań wskazują na niezadowalającą liczbę studentów niepełnosprawnych $^{39}$. Mimo że z każdym rokiem wzrasta liczba osób niepełnosprawnych podejmujących studia, to jednak nadal za mały odsetek osób niepełnosprawnych stara się o przyjęcie do szkół średnich i kończy je, z powodzeniem zdając egzamin maturalny. Znane są $\mathrm{w}$ literaturze przedmiotu wyjaśnienia mechanizmów funkcjonowania niesłyszących na poziomie wyższym ${ }^{40}$. Kształcenie osób z uszkodzonym słuchem na poziomie wyższym ujawnia wiele nowych, nieznanych powszechnie problemów. System reguł i wy-

38 P. Tomaszewski, Funkcjonowanie jezykowo-poznawcze u dzieci głuchych Edukacja głuchych. Materiaty konferencyjne, RPO Warszawa 2014, s. 23.

39 I. Chrzanowska, Student z niepetnosprawnościa - szanse i wyzwania, [w:] Student z niepetnosprawnością w szkole wyższej, red. B. Tylewska-Nowak, W. Dykcik, Wydawnictwo Uniwersytetu Adama Mickiewicza. Poznań 2013, s. 65-85; J. Lipińska-Lokś, Szkoła wyższa w trosce o spoteczna integrację osób z niepetnosprawnościa, [w:] Student $z$ niepetnosprawnościa $w$ szkole wyższej..., s. 101-116; Z. Polak, Studiowanie osób $z$ niepetnosprawnościa UMCS - realia $i$ wyzwania, [w:] Wielowymiarowość integracji w teorii i praktyce ksztatcenia w Uczelni Wyższej, red. B. Harań, Akademia Podlaska, Siedlce 2002.

${ }^{40}$ D. Podgórska-Jachnik, Gtusi. Emancypacje...; B. Szczepankowski, Niestyszący Głusi - Głuchoniemi. Wyrównywanie szans, WSiP, Warszawa 1999. 
magań, na jakich opiera się uzyskiwanie zaliczeń i zdawanie egzaminów, jest niejako w naturalny sposób związany ze specyfiką oceniania ich osiągnięć. Jest to uzasadnione zamierzoną praktyką powiązania możliwości studenta niesłyszącego $\mathrm{z}$ wymaganiami w związku z procesem studiowania. Narzuca to współczesnej edukacji nowe zadania dotyczące całego systemu kształcenia niesłyszących, głównie szczegółowych standardów dla absolwentów szkół na poszczególnych poziomach kształcenia. Zasięg i dynamika zmian w edukacji poprzez różne wybory dróg edukacyjnych powoduje m.in. zasadność kształtowania wzorców dostępności szkoły wyższej dla osób niesłyszących, dookreślenia przestrzeni ich rozwoju.

\section{Sprzeczność interesów w zakresie nauki języka}

Wykorzystanie języka migowego w komunikacji może być rozumiane jak "papierek lakmusowy" funkcjonowania w społeczności głuchych. PJM łączy swoich zwolenników, dla których język ten stał się nie tylko środkiem komunikacji, ale również ich symbolem rozpoznawczym. Ten właśnie symbol na przestrzeni lat spowodował, że osoby głuche mówią o sobie jako mniejszość językowa, która nie tylko porozumiewa się $\mathrm{w}$ innym języku, ale również buduje odrębność społeczną ${ }^{41}$. Jak podkreśla P. Tomaszewski, nie chodzi jedynie o zakładanie rodzin i zrzeszanie osób niesłyszących $\mathrm{w}$ jednym miejscu, ale również o aktywność we wszystkich sferach społecznych i kulturowych. Słowo „Głuchy” pisane wielką literą oznacza członka określonej mniejszości językowej - osobę, dla której język migowy (w Polsce PJM) jest pierwszym i/lub preferowanym sposobem porozumiewania się. Do tak rozumianych głuchych mogą należeć osoby całkowicie niesłyszące, niedosłyszące, a nawet CODA - słyszące dzieci niesłyszących rodziców ${ }^{42}$. Specjaliści podkreślają, iż dla Głuchych język migowy jest nie tylko środkiem ko-

${ }^{41}$ https://www.polskieradio.pl/ [20.02.2016].

${ }^{42}$ P. Tomaszewski, i in., Nauczmy się rozumieć nawzajem. Poradnik dla styszacych niedostyszących $i$ głuchych, Polski Związek Głuchych Zarząd Główny, Warszawa 2010. 
munikowania i swobodnej konwersacji, ale także nośnikiem tradycji i kultury ${ }^{43}$. Osoby te prowadzą ostatnio pewnego rodzaju kampanię na rzecz popularyzacji Polskiego Języka Migowego.

Regulacje podjęte przez główne ośrodki decyzyjne państwa określiły pewne przywileje niesłyszących w zakresie komunikacji. Prezydent Bronisław Komorowski podpisał 12 września 2011 r. ustawę o języku migowym i innych środkach komunikowania się, która m.in. zobowiązuje organy administracji publicznej do zapewnienia osobom niesłyszącym pomocy tłumacza języka migowego ${ }^{44}$. Wiąże się z nią społeczny kontekst dotyczący funkcjonowania systemu komunikacji migowej (Polski Język Migowy i System Językowo-Migowy - SJM). Warto podkreślić, iż projekt ustawy o języku migowym i innych środkach wspierania komunikowania się nie spełnia podstawowych oczekiwań środowiska osób niepełnosprawnych oraz nie wypełnia międzynarodowych zobowiązań Polski w tym zakresie. Zobowiązuje on instytucje publiczne m.in. do bezpłatnego zapewnienia usług tłumacza języka migowego petentom. Z tego obowiązku są jednak zwolnione np. szkoły. Ponadto żadne przepisy nie przewidują możliwości bezpłatnego korzystania z tłumacza języka migowego podczas komunikacji osoby niesłyszącej np. w kontekście prawno-sądowym poza rozprawą, czyli w sekretariacie sądu.

Dla dynamiki emancypacji niesłyszących niektóre rezultaty wprowadzenia ww. Ustawy są znacznie skromniejsze niż można było się spodziewać. Wydaje się, że towarzyszy jej poczucie zagrożenia dla środowiska Głuchych w zakresie porozumiewania się. Według prezesa IPJM, Małgorzaty Czajkowskiej-Kisil istotne dla środowiska Głuchych jest wykorzystanie języka migowego ${ }^{45}$. Uważa ona, że właśnie integracja powoduje osłabienie tożsamości popu-

43 D. Podgórska-Jachnik, Głusi. Emancypacje..., s. 126-127.

44 https://www.pfron.org.pl/pl/wydarzenia/1230,Prezydent-RP-podpisuje-usta we-o-jezyku-migowym.html [20.02.2016].

${ }^{45}$ M. Czajkowska-Kisil, A. Klimczewska, Rola języka migowego w ksztattowaniu tożsamości Głuchych w Polsce, [w:] Tożsamość społeczno-kulturowa Głuchych, PZG Oddział łódzki, Łódź 2007. 
lacji. W praktyce istnieją dwa sposoby posługiwania się znakami migowymi:

- w formie PJM, języka migowego z własną gramatyką o charakterze wizualno-przestrzennym i pozycyjnym (odpowiadający na oczekiwania Głuchych),

- w formie tzw. systemu językowo-migowego - połączenia mowy dźwiękowej w polszczyźnie fonicznej z właściwą jej gramatyką oraz znaków migowych ilustrujących wypowiedź słowną (odpowiadający na oczekiwania niesłyszących i słabosłyszących).

Niemożność sprostania rosnącym oczekiwaniom całego środowiska osób z wadą słuchu utrudnia praktyka, gdzie formy te w czystej postaci występują rzadko, najpopularniejszą formą porozumiewania się są warianty pośrednie między PJM a SJM, co wynika ze stałej interferencji polszczyzny z językiem migowym w okresie nauki szkolnej46.

Dalszy wzrost działań emancypacyjnych z jednej strony wiąże się ze zbyt szybkim rozszerzeniem obszaru wpływów Głuchych i przyjęcia PJM do systemu oświaty, a z drugiej strony niesłyszący chcieliby korzystać z szerokiej oferty oraz dogodnego indywidualnego dostępu do najlepszego języka w praktyce szkolnej. Aktualnie ważne wydaje się dookreślenie odnotowanych zaleceń ułatwiania nauki języka migowego. Chodzi o zapewnienie, że edukacja osób głuchych będzie prowadzona w najodpowiedniejszym języku i przy pomocy sposobów i środków komunikacji najodpowiedniejszych dla jednostki oraz w środowisku, które maksymalizuje rozwój edukacyjny i społeczny.

\section{Porównanie uzyskanych zmian w regulacjach prawnych do oczekiwań w zakresie nauki języka migowego}

Prawo jest węzłowym obszarem dostosowawczym, który w znacznym stopniu determinuje poszukiwania emancypacyjne niesłyszą-

46 B. Szczepankowski, D. Koncewicz, Jezyk migowy w terapii, Wyższa Szkoła Pedagogiczna, Edukacyjna Grupa Projektowa, Łódź 2008. 
cych. Zwróćmy uwagę na regulacje prawne wspomagające proces kształcenia i wychowania niesłyszących:

- prawo do edukacji bez dyskryminacji i na zasadach równych szans gwarantowane jest przez art. 24 Konwencji ONZ o prawach osób niepełnosprawnych,

- akty prawne regulujące system oświaty w Polsce,

- możliwości wyrównywania szans edukacyjnych niesłyszących zawarte w rozporządzeniach Ministerstwa Edukacji Narodowe.

Część środowiska głuchych uważa, iż chodzi o zmianę, w której państwo zobowiązuje się do wprowadzenia w życie zawartych w Konwencji standardów wprowadzenia ułatwień w nauce języka migowego z jednoczesnym poparciem dla rozwoju tożsamości językowej społeczności osób głuchych. Ograniczeniem wydaje się brak refleksji, iż priorytetem w przestrzeni edukacyjnej jest indywidualny dobór najodpowiedniejszego środowiska i języka, co nie musi być jednoznaczne z dominacją PJM.

W Polsce systematycznie wdrażany jest plan działania zgodny z założeniami Strategii Europy 2020 oraz Europejskiej Strategii w Sprawie Niepełnosprawności 2010-202047. W opublikowanych komunikatach podkreślone zostały obszary działań dla Polski zgodnie z europejskimi wytycznymi. W celu ich osiągnięcia zaproponowano realizację priorytetów m.in. w zakresie edukacji za pomocą nadrzędnych celów, takich jak np. "Młodzież w drodze”. Wymaga on poprawy jakości na wszystkich poziomach edukacji i obejmuje różnego rodzaju oddziaływania, w których zakłada się zagwarantowanie wszystkim dzieciom dobrego startu w przyszłość.

W obliczu szerokiego nastawienia na działanie w ramach Europejskiej Konwencji o Ochronie Praw Człowieka szczególnego znaczenia nabiera tzw. prawo do edukacji bez dyskryminacji na zasadach równych szans gwarantowane przez art. 24 Konwencji ONZ. Gwarantuje najbardziej sprzyjające warunki do wzrostu i odpowiedzialności z korzystania wolności przez niesłyszących w zakresie

${ }^{47}$ https://www.rpo.gov.pl/ [6.01.2016]. 
języka. Polska w 2012 r. ratyfikowała Konwencję ONZ o prawach osób niepełnosprawnych, której podstawowym celem jest zapewnienie pełnego i równego korzystania z praw człowieka i podstawowych wolności przez osoby z niepełnosprawnościami, na równi z wszystkimi innymi obywatelami ${ }^{48}$. Poza zobowiązaniem do jego realizacji przez państwo konieczne jest w praktycznym jego stosowaniu odpowiedzialne tłumaczenie $\mathrm{z}$ języka angielskiego na język polski.

Niestety w praktyce trudno mówić o zadawalającej skuteczności proponowanych działań. Otóż nauczyciele, dyrektorzy, a także rodzice i sami uczniowie nie mają wspólnej interpretacji art. 24 Konwencji. Ten sam artykuł jest odmiennie rozumiany przez wszystkich zainteresowanych, co powoduje funkcjonowanie przynajmniej dwóch wersji Konwencji ONZ. Szczególnie chodzi o polemikę, czy ma to być najodpowiedniejszy język, czy tylko język migowy. Czy należy specjalnie udowadniać, że Konwencja daje równe szanse wszystkim osobom z wadą słuchu proponując m.in.:

1) ułatwiania nauki języka migowego i zapewnienia, że edukacja osób głuchych będzie prowadzona w najodpowiedniejszym języku_i przy pomocy sposobów i środków komunikacji najodpowiedniejszych dla jednostki_oraz w środowisku, które maksymalizuje rozwój edukacyjny i społeczny (zgodne z wizją środowiska uwzględniającego warunki dla wszystkich osób z wadą słuchu);

2) zobowiązując się tym samym do wprowadzenia w życie zawartych $\mathrm{w}$ niej standardów m.in. wprowadzenia ułatwień $\mathrm{w}$ nauce języka migowego i popieranie tożsamości językowej społeczności Głuchych (zgodne z wizją środowiska kulturowo Głuchych).

Wystarczy przypomnieć, że nie dla wszystkich głuchych najlepsza droga edukacji prowadzi przez wykorzystanie PJM. Problem polega jednak na tym, żeby jednocześnie zminimalizować zagrożenia wynikające $z$ zepchnięcia na peryferie ograniczenia dostępu, dla

${ }^{48}$ http://www.niepelnosprawni.pl/ledge/x/179419 [6.01.2016]. 
których nauka odbywa się w języku polskim, jednak język ten nie jest percepcyjnie dostępny ${ }^{49}$. Bariera językowa może dotyczyć:

- głuchego dziecka rodziców słyszących, którzy nie zawsze zapewnią mu język komunikacji (ani oralnej ani migowej),

- głuchego dziecka rodziców słyszących ze wszczepionym CI (potrzebuje rehabilitacji mowy).

W praktyce problem narasta, gdyż decydenci znajdują się pod presją żądań i oczekiwań zarówno ze strony osób indywidualnych, jak i całych grup, które domagają się realizacji postanowień Konwencji ONZ. Wyjątkowość tej sytuacji wiąże się z utrzymaniem strefy wpływów. Sami głusi we własnym środowisku usprawiedliwiają wszelkie działania, które mogłyby w przyszłości dla osób z wadą słuchu zakończyć się powszechnym zanikiem naturalnego języka migowego. Przykładem mogą być reakcje jakie w środowisku głuchych wzbudził kontrowersyjny film science fiction "The End" osnuty na przewidywanych osiągnięciach nauki, dzięki którym na całym świecie nie byłoby potrzeby używania języka migowego ${ }^{50}$.

W Polsce niesłyszący nie są uznani za mniejszość językową. W wielu krajach społeczności Głuchych mają status mniejszości językowych i kulturowych ${ }^{51}$. Wyrazem myślenia, iż powinni być uznani za mniejszość językową, jest obok żądań z tym związanych pisownia słowa głuchy/Głuchy. Warto $\mathrm{w}$ tym miejscu podkreślić sprawę upowszechnienia nowych zasad postępowania wobec mniejszości. „Polityczna poprawność” nakazuje identyczne traktowanie wszystkich osób, we wszelkich sytuacjach społecznych, chodzi tu o sprawiedliwe traktowanie oraz przestrzeganie należnych praw osób niepełnosprawnych. Karta Praw Osób Niepełnospraw-

49 https://www.rpo.gov.pl/[6.01.2016].

${ }^{50}$ http:/ / glusi.pl [20.02.2015].

51 P. Wojda, Kompetencje w języku migowym u młodzieży głuchej, [w:] Młodzież głucha $i$ stabostysząca w rodzinie i otaczającym świecie - dla terapeutów, nauczycieli, wychowawców i rodziców, red. J. Kobosko, Stowarzyszenie „Usłyszeć Świat”, Warszawa 2009; J. Kobosko, Psychologiczne implikacje głuchoty dziecka w rodzinie $i$ środowisku szkolnym, [w:] Edukacja głuchych materiaty konferencyjne Warszawa BRPO, Warszawa 2014, s. 41-63. 
nych gwarantuje pełny dostęp do nauki, pracy oraz uczestnictwa w życiu społecznym, publicznym, kulturalnym, artystycznym, sportowym, zgodnie z potrzebami i zainteresowaniami ${ }^{52}$.

\section{Podsumowanie}

Szeroki zakres zagadnień związanych z emancypacją osób niesłyszących dotyczy zarówno perspektywy teoretycznej, jak i praktycznej. Badacze populacji osób z wadą słuchu reprezentują rożne dyscypliny i koncepcje teoretyczne, co przekłada się na głębokie różnice terminologiczne oraz rozumienie aktualnych działań emancypacyjnych. Rozstrzygnięcia w regulacjach prawnych wskazują na zmiany w celu usunięcia ograniczeń w dostępie do uzyskania równych praw, edukacji, inkluzji i komunikacji. Oczekiwania samych niesłyszących $w$ drodze do emancypacji determinowane są różnorodnością oraz specyfiką ich funkcjonowania (niejednorodność populacji), odmiennymi dążeniami do autonomii oraz skomplikowanymi żądaniami dotyczącymi dostępu do języka migowego.

W ramach nurtu emancypacyjnego wspomniano o odrębnych oczekiwaniach części zbiorowości osób z wadą słuchu, ze względu na silną pozycję, jaką zdobyło środowisko Głuchych, podejmując liczne próby zwiększenia dostępu do informacji ${ }^{53}$. Chodzi zwłaszcza o prawo do używania języka migowego, większą przestrzeń publiczną dla osób głuchych, obecność np. bezpłatnych tłumaczy, napisy/ekrany z tłumaczem na dworcach, lotniskach, szpitalach itp.

Zdaniem autorki oczekiwania niesłyszących wyrażają również istotny dylemat współczesnej demokracji, który nie powinien polegać na postrzeganiu rzeczywistości jako "gry o sumie zerowej" gdzie, żeby coś zyskać, zabiera się innym deficytowe dobro ${ }^{54}$.

52 http:// www.niepelnosprawni.pl/ledge/x/997 [6.01.2016].

${ }^{53} \mathrm{http}: / /$ resgest.pl/wp-content/uploads/2016/01/zatrudnij_gluchych_broszu ra.pdf [15.03.2016]

${ }^{54}$ R. Wright, Nonzero. Logika ludzkiego przeznaczenia, Prószyński i S-ka, Warszawa 2005. 
W dynamicznej grze można rozważyć alternatywne podejście, w ramach którego w "grze o sumie niezerowej” może być tak, że wszyscy mogą zyskać, gdyż rozszerzenie zakresu kooperacji, przyniesie korzyści wszystkim współpracującym stronom.

Instrumenty pobudzające aktywność działań niesłyszących w poszukiwaniach dróg emancypacji to także promocja inicjatyw indywidualnych osób, organizacji i stowarzyszeń. Skłaniają one do ponownego spojrzenia m.in. na edukację młodych niesłyszących, którzy chcą zająć dobrą pozycję w społeczeństwie z perspektywą zdobycia wolności. W stymulacji zmian przydatne są wszystkie formy i działania polegające na zwiększeniu liczby osób samodzielnych, elastycznych i otwartych na wyzwania w codziennym funkcjonowaniu, w edukacyjnej praktyce, na rynku pracy. Warunkiem poszerzania obszaru emancypacji powinno być przyjęcie za punkt wyjścia ogólnych zasad równości i sprawiedliwości. Emancypacja ma wiele źródeł, skumulowanie wypływających z nich możliwości umożliwia tworzenie i rozwój każdej osoby niesłyszącej. Stąd pojawiają się nowe wyzwania dla działań edukacyjnych, potrzeba zapewnienia możliwości współpracy i wzajemnego rozpoznania dla niejednolitej populacji.

\section{Bibliografia}

Bartnikowska U., Sytuacja społeczna i rodzinna styszących dzieci niestyszących rodziców, Wydawnictwo edukacyjne AKAPIT, Toruń 2010.

Chrzanowska I., Student z niepetnosprawnościa - szanse $i$ wyzwania, [w:] Student z niepetnosprawnościa w szkole wyższej, red. B. Tylewska-Nowak, W. Dykcik, Wydawnictwo Uniwersytetu Adama Mickiewicza, Poznań 2013.

Csanyi Y., Stuchowo-werbalne wychowanie dzieci z uszkodzonym narządem stuchu, WSiP, Warszawa 2004.

Czajkowska-Kisil M., A. Klimczewska, Rola języka migowego w kształtowaniu tożsamości Głuchych w Polsce, [w:] Tożsamość społeczno-kulturowa Głuchych, PZG Oddział łódzki, Łódź 2007.

Czerepaniak-Walczak M., Między dostosowaniem a zmianą. Elementy emancypacyjnej teorii edukacji, Wydawnictwo Naukowe Uniwersytetu Szczecińskiego, Szcze$\operatorname{cin} 1995$. 
Czerepaniak-Walczak M., Pedagogika emancypacyjna, rozwój świadomości krytycznej człowieka, Gdańskie Wydawnictwo Psychologiczne, Gdańsk 2006.

Dryżałowska G., Rozwój językowy dziecka z uszkodzonym stuchem a integracja edukacyjna. Model kształcenia integracyjnego, Wydawnictwo Uniwersytetu Warszawskiego, Warszawa 2007.

Gunia G., Terapia logopedyczna dzieci z zaburzeniami stuchu i mowy. Wybrane problemy teorii i praktyki surdologopedy, Oficyna Wydawnicza „Impuls”, Kraków 2006.

Hoffman B., Surdopedagogika w teorii i praktyce, WSP TWP, Warszawa 2001.

Kobosko J., Edukacja głuchych. Materiaty konferencyjne, RPO, Warszawa 2014.

Kobosko J., Psychologiczne implikacje głuchoty dziecka w rodzinie i środowisku szkolnym, [w:] Edukacja głuchych materiaty konferencyjne Warszawa BRPO, Warszawa 2014.

Korzon A., Znaczenie jezyka migowego we wczesnej komunikacji dzieci z zaburzeniami stuchu, [w:] Dziecko niepetnosprawne. Rozwój i wychowanie, red. E. Minczakiewicz, Oficyna Wydawnicza „Impuls”, Kraków 2003.

Kosakowski C., Dziecko niepetnosprawne w szkole masowej - możliwości i ograniczenia, [w:] Dziecko o specjalnych potrzebach edukacyjnych, red. C. Kosakowski, M. Zaorska, Wydawnictwo Edukacyjne, Torun 2000.

Kostyło H., Przestanie „Pedagogii uciśnionych” Paula Freire, „Forum Oświatowe” 2011, nr 2(45).

Kowalski P., Rekomendacje organizacyjne dla szkolnictwa dla Głuchych, [w:] Edukacja głuchych. Rzecznik Praw obywatelskich, RPO, Warszawa 2014.

Krakowiak K., Kim jest moje niestyszace dziecko?, [w:] „Nie głos, ale stowo...”. Przekraczanie barier w wychowaniu osób z uszkodzeniami stuchu, red. K. Krakowiak, A. Dziurda-Multan, Wydawnictwo KUL, Lublin 2006.

Krakowiak K., Pedagogiczna typologia uszkodzeń stuchu i osób nimi dotkniętych, [w:] "Nie głos, ale słowo...". Przekraczanie barier w wychowaniu osób z uszkodzeniami stuchu, red. K. Krakowiak, A. Dziurda-Multan, Wydawnictwo KUL, Lublin 2006.

Krakowiak K., Szkice o wychowaniu dzieci z uszkodzeniami stuchu. Oficyna Wydawnicza Fundacji Uniwersyteckiej w Stalowej Woli, Stalowa Wola 2003.

Krause A., Niepetnosprawność-Inny w paradygmacie humanistycznym, [w:] Niepetnosprawność Pótrocznik Naukowy - Problemy Wybrane/Niepetnosprawność w aspekcie zdrowia i życia społecznego, Surdopedagogika, red. A. Krause 2010, nr 4.

Krause A., Teoretyczne inspiracje pedagogiki specjalnej - pedagogika emancypacyjna, „Studia Edukacyjne” 2013, nr 28, s. 7-16.

Lipińska-Lokś J., Szkoła wyższa w trosce o społeczna integrację osób z niepetnosprawnościa, [w:] Student z niepetnosprawnością w szkole wyższej, red. B. Tylewska-Nowak, W. Dykcik, Wydawnictwo Uniwersytetu Adama Mickiewicza, Poznań 2013.

Plutecka K., Kompetencje zawodowe surdopedagoga z wada stuchu, Oficyna Wydawnicza „Impuls”, Kraków 2006.

Podgórska-Jachnik D., Głusi. Emancypacje, Wydawnictwo Naukowe WSP, Łódź 2013. 
Podgórska-Jachnik D., Głusi wśród styszących - głusi wśród Głuchych. Problemy integracji społecznej osób z uszkodzonym stuchem w aspekcie tożsamościowym, [w:] Tożsamość społeczno-kulturowa głuchych. Polski Związek Głuchych Oddział Łódzki, red. E. Woźnicka, Łódź 2011.

Polak Z., Studiowanie osób z niepetnosprawnościa UMCS - realia i wyzwania, [w:] Wielowymiarowość integracji w teorii i praktyce kształcenia w Uczelni Wyższej, red. B. Harań, Akademia Podlaska, Siedlce 2002.

Raj-Koziak D., Sprawozdanie z 9th Internayional TRI Tinnitus Conference 'Tinnitus: from Cochlea to Brain and Back" 7-10.06.2015 Ann Arbor USA, "Nowa Audiofonologia" 2015, nr 4(3) s. 84-85.

Sak M., Kształcenie głuchych $w$ szkołach masowych $i$ w klasach mieszanych $z$ innymi niepetnosprawnościami, wystąpienie na Konferencji Edukacja Głuchych 20.032014

Skarżyński H., Mueller-Malesińska M., Wojnarowska W., Klasyfikacja zaburzeń stuchu, „Logopedia” 2002, nr 28.

Szczepankowski B., Osoby z uszkodzonym stuchem, [w:] Problem niepetnosprawności w poradnictwie zawodowym. Zeszyty Informacyjno Metodyczne Doradcy Zawodowego, nr 10, red. B. Szczepankowski, A. Ostrowska, Warszawa 1998.

Szczepankowski B., Niestyszacy - Głusi - Gluchoniemi. Wyrównywanie szans, WSiP, Warszawa 1999.

Szczepankowski B., Jezzyk migowy a mowa ciata, [w:] Mowa ciała i jej funkcje w kulturze, red. M. Jasińska, J. Kuć, Wydawnictwo Akademii Podlaskiej, Siedlce 2002.

Szczepankowski B., Koncewicz D., Jezzyk migowy w terapii, Wyższa Szkoła Pedagogiczna, Edukacyjna Grupa Projektowa, Łódź 2008.

Śliwerski B., Edukacja alternatywna. Dylematy teorii i praktyki, Oficyna Wydawnicza „Impuls”, Kraków 1992.

Śliwerski B., Wspótczesne teorie i nurty wychowania, Oficyna Wydawnicza "Impuls”, Kraków 2003.

Tomaszewski P., i in., Nauczmy się rozumieć nawzajem. Poradnik dla styszących niedosłyszących $i$ głuchych, Polski Związek Głuchych Zarząd Główny, Warszawa 2010.

Tomaszewski P., Funkcjonowanie jezzykowo-poznawcze u dzieci głuchych Edukacja głuchych. Materiaty konferencyjne, RPO Warszawa 2014.

Tomaszewski P., Rozwijanie kompetencji socjokulturowej w nauczaniu polskiego jezyka migowego, [w:] Społeczne $i$ kulturowe aspekty zdrowia i niepetnosprawności, red. P. Tomaszewski, K. Bargiel-Matusiewicz, E. Pisula, Wydawnictwo UW, Warszawa 2015.

Twardowska E., Kowalska M., Katalog szkót 2011/2012, Wydawnictwo PZG, Łódź 2011.

Wright R., Nonzero. Logika ludzkiego przeznaczenia, Prószyński i S-ka, Warszawa 2005.

Werszka K., Bieńkowska-Robak K., Problemy ze stuchem, „Integracja” 2002, nr 6. 


\section{Źródła internetowe}

http://glusi.pl/contentpjm/index.php?option=com_hwdvideoshare\&task=viewvideo \&Itemid=435\&video_id=235 film „The End" [20.02.2016].

http://rozprawyspoleczne.pswbp.pl/pdf/03_rs_t6_nr1_2012_trebicka_postrzygacz, _antas.pdf [15.03.2016].

http://www.efs.2007-2013.gov.pl/analizyraportypodsumowania [15.03.2016].

http://www.wydawnictwo.wsp.lodz.pl/glusi/glusi_www_calosc.pdf [15.03.2016]. https://rpo.gov.pl/sites/default/files/Edukacja_gluchych_materialy_konferencyj ne.pdf

https://www.pfron.org.pl/pl/wydarzenia/1230,Prezydent-RP-podpisuje-ustawe-ojezyku-migowym.html [20.02.2016].

https://www.rpo.gov.pl/sites/default/files/Edukacja\%20gluchych.pdf [6.01.2016]. https://www.efs.20072013.gov.pl/analizyraportypodsumowania/baza_projektow_ badawczych_efs/strony/ogolnopolskie_badanie_syt_potrzeb_2009_28032011.aspx [6.01.2016].

https:/ / Documents\%20and\%20Settings/uw/Pulpit/194-594-1-SM.pdf [12.02.2016]. http://glusi.pl [dostęp: 20.02.2015].

http://resgest.pl/wp-content/uploads/2016/01/zatrudnij_gluchych_broszura.pdf [15.03.2016].

http://www.youtube[17.02.2016].

https://www.onsi.pl [17.02.2016].

http://www.youtube.com/watch?v=modq8QpKmE4 [20.02.2016].

https://men.gov.pl/niezbednik[20.02.2016].

https://www.polskieradio.pl/ [20.02.2016].

http://www.bip.men.gov.pl/index.php [15.03.2016].

http://www.niepelnosprawni.pl/ledge/x/179419 [6.01.2016].

http://www.niepelnosprawni.pl/ledge/x/997 [6.01.2016].

https://www.rpo.gov.pl/[6.01.2016]. 